\title{
The Influences of Sponge City on Property Values in Wuhan, China
}

\author{
Shiying Zhang ${ }^{1}$, Chris Zevenbergen ${ }^{2, *}$, Paul Rabé ${ }^{3}$ and Yong Jiang ${ }^{4}$ \\ 1 SF Express Holding, Wuhan 430015, China; pattyzsy@hotmail.com \\ 2 Department of Water Science Engineering, IHE Delft Institute for Water Education, \\ 2611 AX Delft, The Netherlands \\ 3 Institute for Housing and Urban Development Studies (IHS), Erasmus University Rotterdam, \\ 3000 DR Rotterdam, The Netherlands; rabe@ihs.nl \\ 4 Department of Integrated Water Systems and Governance, IHE Delft Institute for Water Education, \\ 2611 AX Delft, The Netherlands; y.jiang@un-ihe.org \\ * Correspondence: c.zevenbergen@un-ihe.org; Tel.: +31-653-599-654
}

Received: 7 May 2018; Accepted: 2 June 2018; Published: 12 June 2018

\begin{abstract}
Rapid urbanization in China and global climate change have increased urban flood exposure in Wuhan, and the increased flood risk has reduced property values in flood-prone areas. The central government of China is promoting the application of the sponge city concept to reduce urban flood risk and improve the environment in cities. Wuhan is one of the pilot cities of this initiative. A shortage of funds is one of the main obstacles to sponge city construction, as is the lack of a suitable business model. To test residents' willingness to pay for sponge city construction, this research analyzed the impact of sponge city construction on the housing values of areas covered by sponge city interventions. The authors conducted interviews and analyzed secondary data to gauge residents' awareness and perceptions of sponge city interventions. The results show that more than half of residents in Wuhan are willing to pay for sponge city measures, but the amount they are willing to pay is limited. Residents are more willing to pay for improvements of their living environment than for flood reduction measures.
\end{abstract}

Keywords: urbanization; flood risk; flood risk management; perceptions of flooding; willingness to pay

\section{Introduction}

During the past 30 years, triggered by economic reforms, China's economy has undergone rapid expansion. Urbanization has been one of the most significant driving forces of this economic expansion. Wuhan is the capital city of Hubei Province and is located in the middle reaches of the Yangtze River. Its history is intertwined with the fight against water and flooding [1]. The Yangtze River and its biggest tributary cross the city's geographic center. This geographic feature means that the water levels of the two rivers have a direct influence on the whole city's safety. Over time, as a result of rapid urbanization, the original lakes and rivers within the city boundaries have been filled in and transformed into impermeable concrete. These man-made transformations have significantly reduced the city's ability to absorb water and have exposed it to regular flooding following heavy rains. Wuhan is one of the top 10 largest cities in China which suffers most from frequent river and pluvial flooding. Wuhan is also a symbol of the uncontrolled, rapid expansion of Chinese cities, resulting in a significant loss of storm water retention capacity and a drainage infrastructure which is unable to keep pace with these changes and growth.

In 2016, two months into the Yangtze River's flooding season, a continual intensive rainfall period affected the catchment area of the Yangtze River (The strongest storm in Wuhan since 1998, Wuhan 
Morning News, 2016; Available online: http:/ /hb.qq.com/a/20160703/004392.htm). The high-water level of the Yangtze River, on the one hand, made it hard to discharge urban water into the river, and, on the other hand, the capacity of the city's pumping station was limited. Partly as a result, on the morning of 6 July 2016, a major part of the city was flooded by rainwater. Roads and metro stations were inundated and trains were cancelled. Because of waterlogging within the city, two main metro lines were out of operation and thousands of cars were inundated by water and trapped on the street. This urban flooding event caused an economic loss of approximately CNY 2.2 billion, and 10 million people in the city were severely affected because of the dysfunction of the transportation system and the power supply system [2].

To deal with the challenges and problems resulting from urban flooding, on 12 December 2014, China's central government launched a policy of promoting the construction of sponge cities. On 31 December 2014, China's Ministry of Finance published its "policy of allowance" related to the construction of sponge cities [3]. This policy of allowance gives a detailed description of how the central government will support the local government in the construction of sponge cities.

Shortly after the central government's announcement, Wuhan city was selected as one of the first batches of pilot cities for sponge city construction. The Wuhan pilot started operations in mid-2015 and was planned to finish by the end of 2017. According to the working plan of Wuhan City Government for sponge city development [4], five objectives related to urban environmental conditions and waterlogging were formulated that should be achieved and checked before the end of 2017. These objectives were intended to restore the city's capacity to absorb, infiltrate, store, purify and drain (rain) water. However, the process of constructing the sponge city has fallen behind schedule, mainly due to insufficient funds.

To promote the construction of sponge city in Wuhan, China's central government committed itself to providing CNY 1 billion to the Wuhan government. However, the funding requirement for sponge city construction was estimated at CNY 15 billion for a period of two years, so the subsidy from the central government is insufficient. The funding shortage was assumed to be financed through private-public partnerships (PPPs). However, non-government sources of finance are difficult to mobilize through PPPs, as there are no successful PPP models to collect revenue from sponge cities currently. Thus, the challenge is to develop a business model for financing sponge city projects to address the lack of public funding. Under these circumstances, it is worth investigating whether the construction of sponge cities can increase housing values, as this may support identification and development of a business model and financing instruments to cover the funding gap. This research analyses the impacts of the construction of a sponge city on the housing values of the area that the sponge city construction covers. If the assumption that sponge city construction can improve property values can be verified, an effective business model may be designed accordingly.

\section{Background and Context}

Over the last two decades, the number of publications on research into the effects of floods and flood hazard on property values has steadily grown. These publications do not (yet) justify a straightforward conclusion: they indicate a range from negative to indifferent effects on property values [5]. These differences are in part a result of different study approaches, data and methods of analysis (e.g., changes to developed residential property values vs. land values) used. One of the conclusions most of these studies share is that an actual flood event seems to have an immediate and greater effect on property values than merely flood risk information provided by, for instance, flood risk maps [5,6]. Flood resistant and resilient retrofitting and repairs made after a flood occurrence generally have a positive effect on property value [7-9].

It is important to note that flood risk is one of many factors affecting property values. Other factors include, chiefly, the demand and the use and location of the property [7]. This, in turn, is typically influenced by legislative differences between countries and regional differences in behaviors and attitudes $[5,10]$. The levels of flood risk experienced by an individual depends on both exogenous 
(which are beyond an individual's control) and endogenous (which can be influenced by individuals by taking actions that reduces risk) factors. With respect to the latter, the willingness to pay (WTP) for flood risk reduction is largely influenced by people's subjective assessment of flood risk (referred to as risk perception), rather than a scientifically observed measure. Hence, citizen perceptions of urban flood hazards are often regarded as important factors influencing their WTP to reduce flood risks and to deploy flood resistant and resilient measures [11]. WTP for flood risk reduction may also be influenced by other factors, such as resource limitations, personality (individual characteristics), current risk levels, and acceptability of risks [11].

Very little information is currently available on the public perception and willingness to pay for sponge city initiatives in China. According to [12], education and income have a positive effect on WTP to support sponge city initiatives in two cities (Zibo and Dongying, Shandong Province) of China. A recent comparative study (UK, USA, China and Germany) on the impacts of flooding on property values has revealed that there is generally a lack of information on the impact of flood risk on land and housing markets at present. With the arrival and inter-comparison of more detailed flood impact data of properties, this will likely change and will allow valuation professionals to better reflect risk in their valuations [7]. The contingent valuation method (CVM) is increasingly used to assess the WTP for flood insurance and structural flood resistant and resilient measures (e.g., [13]). CVM involves a survey-based technique in which people are being asked to directly report their WTP. CVM has received wide application in valuing a variety of nonmarket goods such as wildlife, water quality, various risks, and the value of recreational sites [14].

\section{Materials and Methods}

\subsection{Introduction to the Sponge City Concept}

The sponge city concept is being promoted by the Chinese government to both reduce urban flood risk and improve the urban environment by mimicking natural processes. The approach aims to enhance a city's ability to "absorb, store, permeate and purify rainwater and to make use of stored water when needed" [15]. General targets have been set with regards to the fraction of annual runoff retained, but not to flood exposure and/or impacts. The central government of China promotes sponge cities as a national, holistic strategy to address urban flooding, because they are designed to offer "a more sustainable, integrative solution to the urban flooding problem than traditional storm water management practices, and one that is more closely related to the eco-city and low-carbon city approach" [16].

\subsection{Research Strategy}

This research was based on a combination of a survey (based on CVM) and desk research. For the survey, a questionnaire was used as the main method to explore residents' perceptions of flood risk and the sponge city approach, and to test its influence on housing and land values in central districts of Wuhan. The questionnaire consisted of 27 closed-ended questions (see Appendix A). Interviews were conducted with representatives of the public sector-including the city government and planning institutions- the private sector (including developers and professional service firms), and experts on sponge city approaches, in order to analyze residents' perceptions (Representatives of public sector institutions consulted for qualitative information related to the study were from the Wuhan Housing Security and Housing Management Authority, the Wuhan Municipal Development and Reform Committee, and the Wuhan Land Use and Urban Spatial Planning Research Center). In total, 15 in depth interviews were held between January and March 2017. The method of secondary data analysis was used in the strategy of desk research. Land transaction price data and housing transaction prices in the sponge city areas of Wuhan were analyzed to test whether and to what extent the sponge city program would impact property values. 


\subsection{Data Collection and Analysis}

The online platform called Sojump (https://www.sojump.com/) was used to conduct the questionnaire. The questions were put into the platform by the researcher and the platform produced a unique URL link for the researcher. The researcher sent this link to the target respondents through e-mail and other information sharing tools such as Wechat. Participation in the survey was voluntary.

Based on the population of the central districts in Wuhan at the end of 2015 [17] , and using a confidence level of $95 \%$ at a confidence interval of 5 , a sample size of 384 respondents from the study area(Shows in Figure 1) was established as a representative sample for the survey. Data analysis was undertaken and data were generated using Qualtrics software. To increase the representativeness of the sample, the questionnaire was distributed to residents in all seven districts of central Wuhan. Questionnaires were written in Chinese and list in Appendix A.

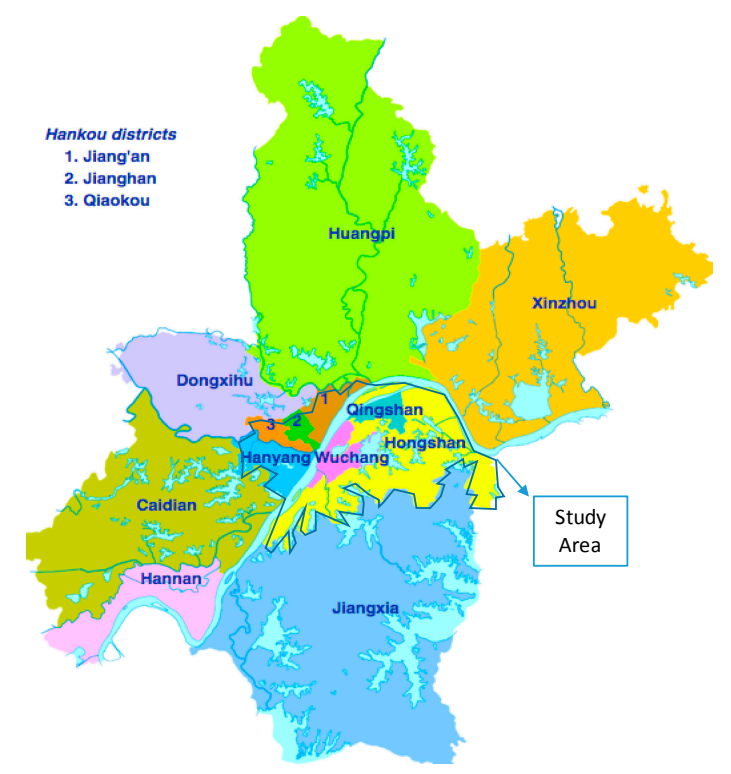

Figure 1. Map of Wuhan City, with the study area (central districts) indicated in blue.

Secondary data analysis was used as a supplement to enable the researchers to have a better understanding of the relationship between sponge city construction and housing values. All secondary data were obtained by visiting the website of those institutions or databases. The secondary data collection covered a period of ten years, from 2007 to 2017. Housing transaction price data covered the same seven central districts of Wuhan as the questionnaire.

\section{Results}

The research findings are presented in three parts. The first part analyses responses to the survey questionnaire. The second part presents qualitative analysis of in-depth interviews of representatives from different sectors. The final part examines collected secondary data of prices for land use rights and houses.

\subsection{Survey Responses}

\subsubsection{Demographic Characteristics of Respondents}

The survey collected 452 sets of responses. Twenty-nine of the respondents did not live in one of the seven central districts of Wuhan and thus were not included in the analysis, resulting in a total sample size of 423 in this study. 
The demographic characteristics of the respondents are shown in Table 1. The primary age range of the respondents was between 18 and 28 years, accounting for $47.5 \%$ of the total samples. Among the respondents there were more females than males. The majority had a college or university degree. The respondents came from seven central districts of Wuhan city, with the relative percentages in the sample equal to at least $10 \%$, implying the sample covered all the central districts of Wuhan (Table 2).

Table 1. Demographic Characteristics of Respondents.

\begin{tabular}{cccc}
\hline Variable & Category & Number of Respondents & Percentage of Respondents \\
\hline \multirow{5}{*}{ Age } & Below 18 & 1 & 0.2 \\
& $18-30$ & 201 & 47.5 \\
& $31-45$ & 88 & 20.8 \\
& $46-55$ & 51 & 12.1 \\
\multirow{2}{*}{ Gender } & $56-65$ & 80 & 18.9 \\
& older than 65 & 2 & 0.5 \\
\hline \multirow{2}{*}{ Education level } & Female & 250 & 59.1 \\
& Male & 173 & 40.9 \\
& Sniversity or college degree & 87 & 20.6 \\
& Post-graduate qualification & 224 & 53 \\
\hline
\end{tabular}

Table 2. Demographic data of central districts in year-end of 2015.

\begin{tabular}{cccc}
\hline District & $\begin{array}{c}\text { Number of Residents } \\
\text { (Unit: Thousand) }\end{array}$ & $\begin{array}{c}\text { Percentage of City } \\
\text { Residents by District }\end{array}$ & $\begin{array}{c}\text { Percentage of Samples } \\
\text { by District }\end{array}$ \\
\hline Jiangan District & 719.5 & $8.7 \%$ & $15 \%$ \\
Jianhan District & 486.4 & $5.9 \%$ & $10 \%$ \\
Qiaokou District & 526.5 & $6.3 \%$ & $11 \%$ \\
Hanyang District & 585.4 & $7.1 \%$ & $12 \%$ \\
Wuchang District & 1056.1 & $12.7 \%$ & $22 \%$ \\
Qingshan District & 433.7 & $5.2 \%$ & $9 \%$ \\
Hongshan District & 948.8 & $11.4 \%$ & $20 \%$ \\
Total & 4756.4 & 57.3 & 100 \\
\hline
\end{tabular}

\subsubsection{The Respondents' Exposure to Urban Flooding}

How residents perceive risk is fundamental to how they respond to flooding and take actions [18]. Flood risk perception is influenced by numerous factors related to the perceived probability of flood occurrence on the one hand and to the perceived consequences on the other hand. Several studies have shown that these factors are closely related to the proximity (distance) to the flood hazard, past experience (flood frequency), and the ability to take preparedness actions [19]. Based on these findings, five indicators were used in our survey to map the flood risk perception of the respondents. These indicators were: flood exposure, flood frequency, flood impact perception, flood protection measures (taken by residents), and perception of floods on property value.

\section{Flood Exposure}

Table 3 shows the extent to which the respondents had been exposed to urban floods over the past twenty years. The survey reveals that $96.7 \%$ of the respondents had been exposed to urban flooding in Wuhan in either a direct or an indirect way. This means that urban residents' exposure level in Wuhan is very high. This high level of exposure to floods indicates the importance for the city to take action and to promote sponge city development in Wuhan.

Flood Frequency

Table 4 shows that about $66.5 \%$ of the respondents experienced flooding at least once a year over the past ten years. 
Table 3. Respondents' exposure to urban floods.

\begin{tabular}{cccc}
\hline Extent of Exposure & Frequency & Percentage & Cumulative Percentage \\
\hline Heavy exposure & 186 & 44 & 44 \\
Limited exposure & 144 & 34 & 78 \\
Observed other's exposure & 79 & 18.7 & 96.7 \\
No exposure & 14 & 3.3 & 100 \\
\hline Total & 423 & 100 & \\
\hline
\end{tabular}

Table 4. Frequency of respondents' exposure to urban floods.

\begin{tabular}{ccc}
\hline Number of Flood Exposure & Frequency & Percentage \\
\hline More than once a year & 109 & 25.8 \\
Once a year & 172 & 40.7 \\
Once per two years & 55 & 13 \\
Once per three to five years & 59 & 13.9 \\
Once per six to ten years & 10 & 2.4 \\
Less than once per ten years & 4 & 0.9 \\
Total & 409 & 96.7 \\
Missing value & 14 & 3.3 \\
Total & 423 & 100 \\
\hline
\end{tabular}

Perception of Flood Impacts

Respondents' perceptions of the consequences of flooding differed depending on their lifestyle (for example, their reliance on public transport) and their proximity to previously flooded areas. Figure 2 suggests that $73 \%$ of the respondents ranked the disruption of public transportation caused by flooding as the most harmful impact, followed by flooding of their neighborhoods (49\% of respondents). In contrast, only $16 \%$ and $23 \%$ of the respondents experienced direct impacts from flooding of their houses and working places, respectively. The damage to private (movable) property was considered less harmful, as only $5 \%$ of the respondents reported property damage and loss. This might be attributed to the fact that flood damage to private property can be reduced as, unlike infrastructure and public buildings, they can be moved to dry places, and are thus less vulnerable to flooding. Respondents also mentioned that floods not only have hygiene and safety impacts but also negatively affect the image of a city.

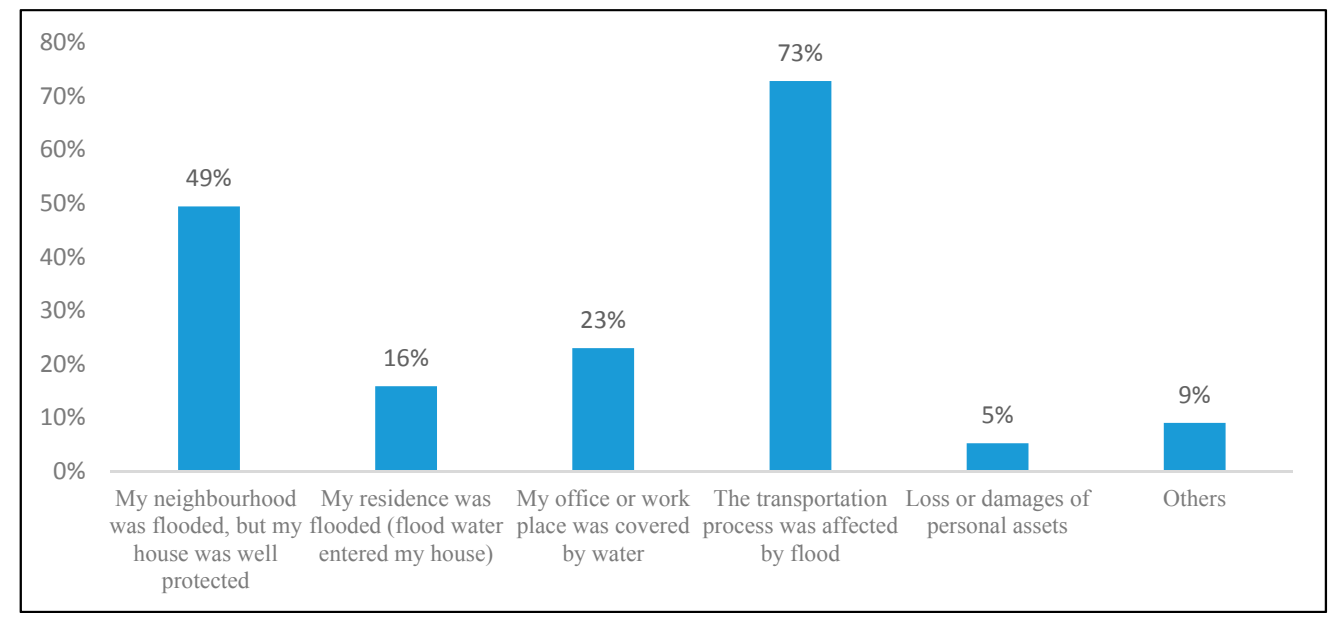

Figure 2. Impacts of urban floods as perceived by survey respondents. 
Flood Protection Measures Taken by Residents

Measures that residents took when responding to urban floods are another important indicator of local perceptions of urban floods. They reflect how local people reacted to flooding and demonstrate their ability to reduce flood impact.

Figure 3 demonstrates that only $4 \%$ of respondents took no action to cope with floods, implying that the majority $(96 \%)$ of the respondents took actions to protect themselves against flooding. The protective measures were dominated by recovery actions (taken after flooding), which accounted for $66 \%$ of the respondents. About $19 \%$ of the respondents claimed to have taken preventive actions to protect their houses and properties from flood water. Measures such as flood barriers, sandbags, and removing valuable assets to dry places were usually deployed, albeit that they were not always perceived as effective. The remaining $11 \%$ of the respondents adopted passive actions, such as temporarily leaving the flooded area.

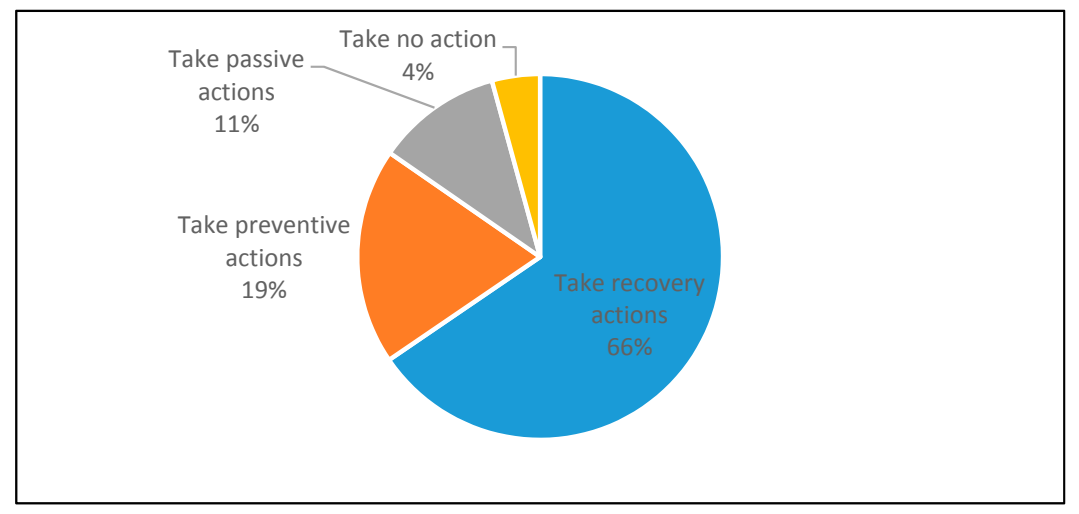

Figure 3. Types of flood protection measures taken by respondents.

Perceptions of Floods and Property Value

Most respondents considered floods to be annoying (59\% of the respondents), as shown in Figure 4. About $14 \%$ of the respondents regarded their flood experience as traumatic and considered evacuating to a dry place as a preferred option. Those who felt neutral or indifferent about floods accounted for $24 \%$ of responses. During the in-depth interviews, two respondents indicated having a neutral attitude toward floods because they got used to them as floods happened every year.

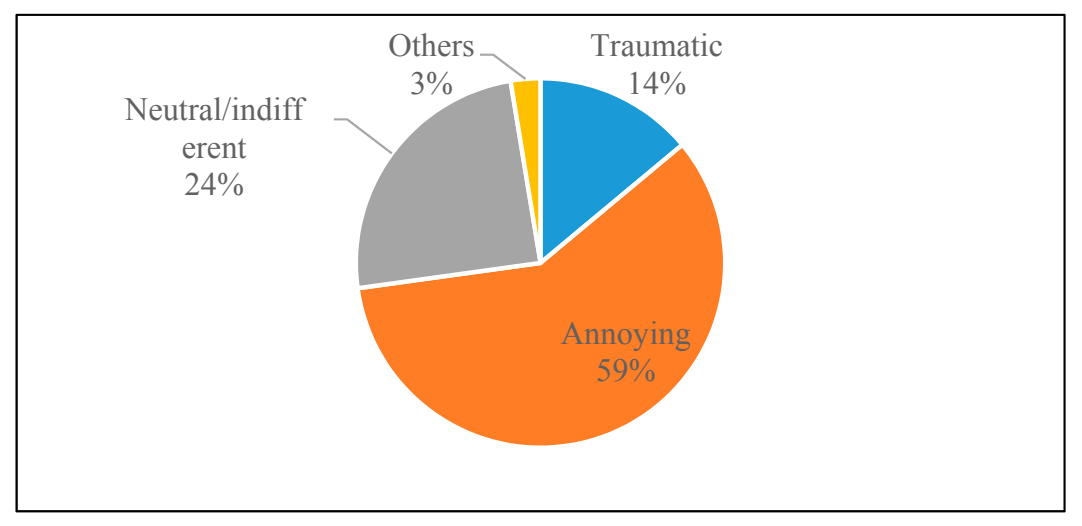

Figure 4. Resident's perceptions of floods.

Figure 5 shows respondents' perceptions of the impact of floods on residential property values. According to the figure, $86 \%$ of the respondents whose properties were exposed to flooding during 
the flooding season suffered from a value decrease compared to residential properties outside the flooded areas. However, $48 \%$ of the respondents expected that the value of the properties in the flooded areas would recover to the level before the flooding if adequate flood protection measures would be implemented. Only $25 \%$ of the respondents indicated that the value of their properties that were flooded would not return to this pre-flood level even after flood protection measures were implemented.

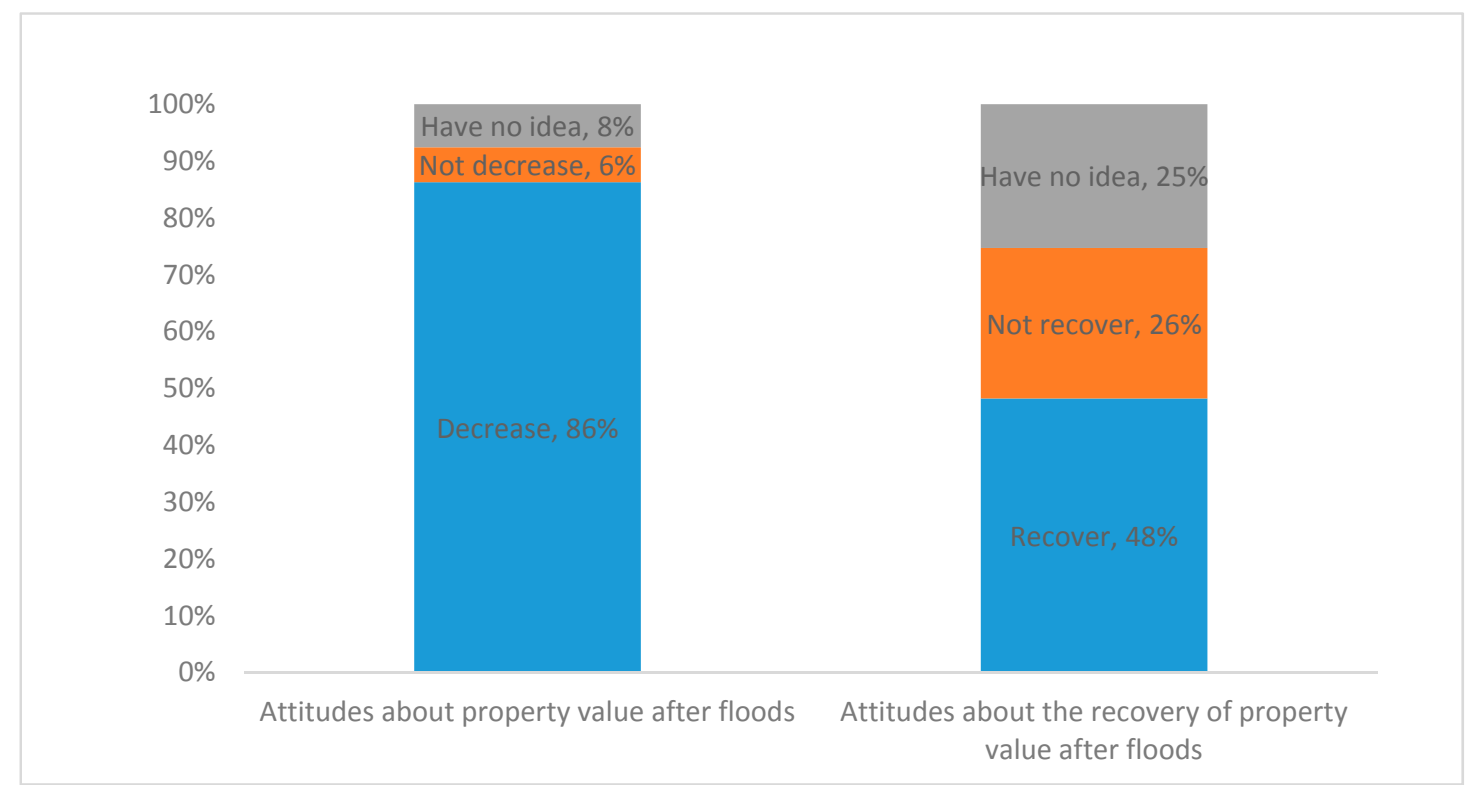

Figure 5. Residents' perceptions of property values after flooding.

\subsubsection{Respondents' Perceptions of Sponge City and Its Functions}

\section{Respondents' Perceptions of Sponge City}

Although the sponge city concept has only recently been introduced, $34 \%$ of the respondents in the central area of Wuhan were to some extent familiar with the concept, and $32 \%$ had heard about it but had no understanding of its meaning (Table 5). As shown in Table 5, 34\% of the respondents did not understand the sponge city concept. As many as $44 \%$ of respondents were aware of the fact that Wuhan is currently implementing the sponge city concept through construction activities associated with urban development.

Table 5. Respondents' perceptions about sponge city.

\begin{tabular}{ccccc}
\hline Knowledge about Sponge City & Perception & Frequency & Percent & $\begin{array}{c}\text { Cumulative } \\
\text { Percent }\end{array}$ \\
\hline \multirow{3}{*}{ Concept of sponge city } & Know & 144 & 34 & 34 \\
& $\begin{array}{c}\text { Do not know } \\
\text { Heard, but have no idea } \\
\text { what it means }\end{array}$ & 143 & 34 & 68 \\
\hline Awareness of sponge city & Yes & 136 & 32 & 100 \\
development in Wuhan & No & 237 & 56 & 44 \\
\hline
\end{tabular}

Respondents' Perceptions of the Functions of Sponge City

During the survey process, the concept of sponge city and its main functions and benefits to cities were introduced to the interviewees. More than two-thirds $(68.1 \%)$ of respondents believed that the construction of sponge city could effectively reduce the negative impact of floods on residential 
properties. Only $5.7 \%$ of respondents did not believe in the effectiveness or usefulness of the sponge city concept. The remaining $26.2 \%$ of the respondents had little idea about the objectives and effects of sponge city construction and shared the opinion that the effectiveness of sponge city projects should be demonstrated first (a "wait-and-see attitude").

The survey also assessed residents' appreciation of the multi-functional benefits of the sponge city concept, including the increase or improvement of the coverage of public green space (amenities) and flood safety (Figure 6). About $80 \%$ of the respondents ranked improvement of green space coverage as the most important benefit, closely followed by flood safety $(74 \%)$ and the improvement of the coverage of public space (73\%). Hence, most respondents thought that the multiple benefits of the sponge city concept were of high relevance and importance.

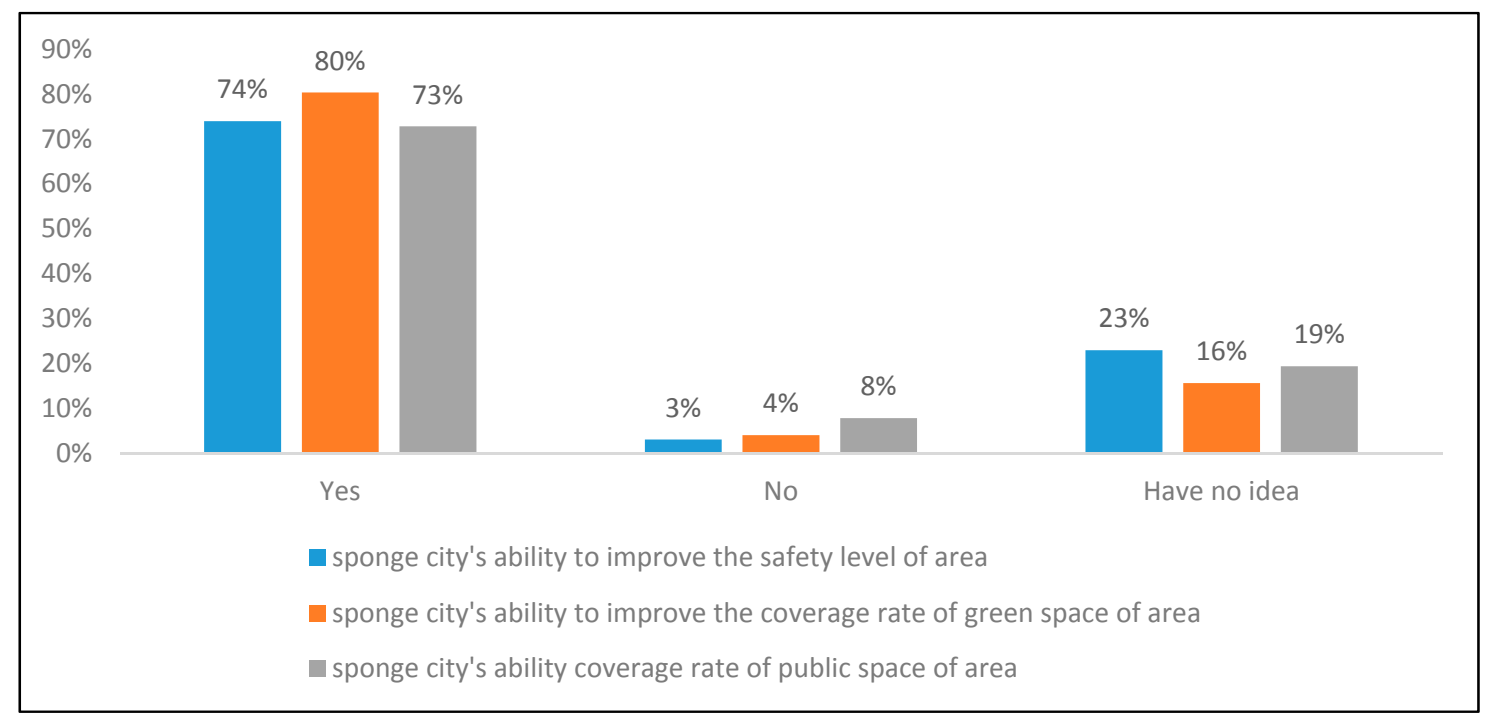

Figure 6. Residence's perceptions of different functions of sponge city.

\subsubsection{Respondents' Willingness to Pay for Sponge City}

Public willingness to pay is a subjective matter that varies from person to person. The heterogeneous nature of WTP is reflected in different perceptions, which in turn are impacted by differences in socio-economic and cultural backgrounds. It is assumed in this study that an important factor affecting residents' WTP for sponge city construction is residents' perceptions of the relationship between property values and the functional benefits attached to property brought about by sponge city construction. In this study, the above-mentioned assumption can be verified. The results show that $17 \%$ and $12 \%$ of the respondents believed sponge city construction would not increase their house value and land value, respectively. However, as shown in Figure 7, most respondents believed sponge city construction would increase their property value: $83 \%$ of the respondents assumed that their house value would increase, of which $50 \%$ expected an increase between $2 \%$ and $11 \%$ of the original house value. The percentages for land value increase are at a lower level than those for house values. In China, residential land is owned by collectives or by the state, and residents do not have the ability to participate in land transactions related to renting land or buying land user-rights. In other words, the perception of land value is biased by Chinese property laws and does not necessarily align with the perception of house values. As a result, $21 \%$ of respondents have no opinion about the impact of the sponge city concept on land values. 


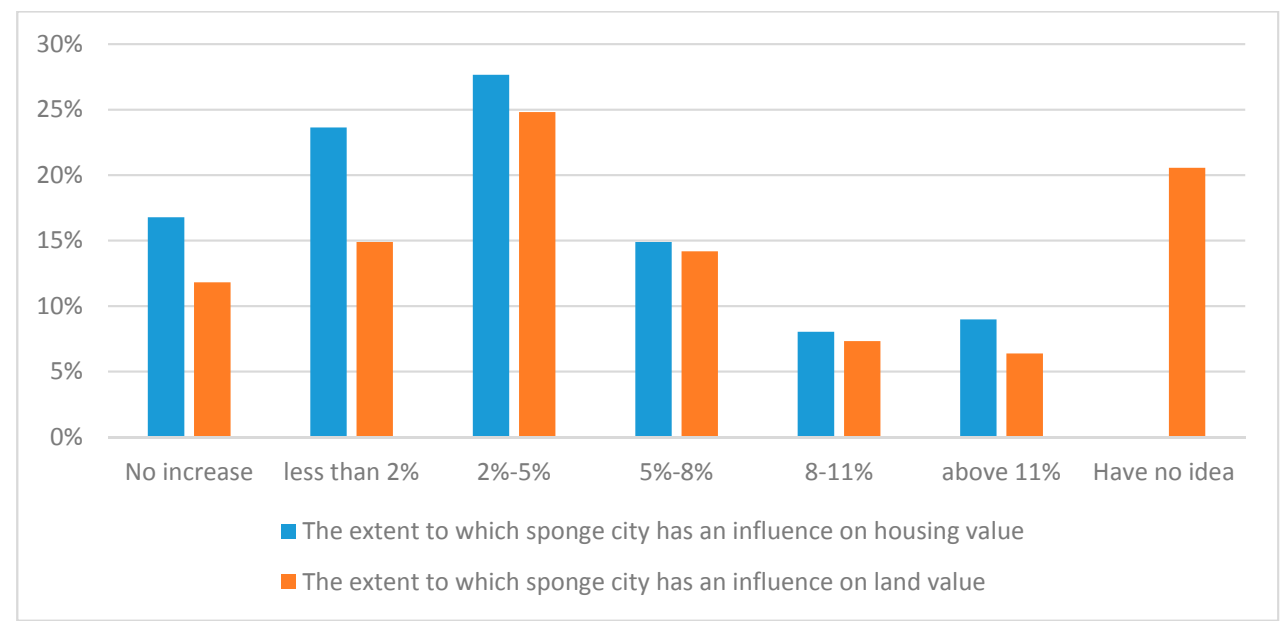

Figure 7. The extent to which sponge city influences housing and land values.

In summary, the data show that respondents were sensitive to flood risk exposure and property values, and were likely to recognize the value of sponge city as they expected their property value to increase. About $83 \%$ of respondents assumed that sponge city construction would increase the house value and $67 \%$ of the respondents expected their land value to increase in areas that the sponge city construction will cover. Most respondents who assumed that sponge city construction would increase their property value expected an increase in property values of less than $5 \%$.

\subsection{Research Findings of in-Depth Interviews}

In-depth interviews were intended to better understand the reasons behind respondents' answers, and to gather professional views on the issues addressed in this research related to sponge city construction. From the interviews, it was found that flood risk exposure in Wuhan varied widely across the city. Most interviewees indicated that urban flooding is influencing their daily life either in a direct or an indirect way. The observed high frequency of flooding and the general notion that the current flood mitigation measures are not sufficient contributed to a certain level of tolerance towards urban flooding among the residents of Wuhan. Residents of Wuhan cared more about water management facilities and the services provided in the city and the multiple benefits emerging from sponge city construction. Only during the rainy season did residents value the benefits from flood safety improvements. During spring and winter time, the environmental effects of green infrastructure associated with sponge city construction were valued most, as green infrastructure was perceived to contribute to reducing air-pollution problems of the city.

Urban flood management approaches have significantly influenced urban design and construction policies and practices in recent years (e.g., [20]). In the past, citizens' involvement in flood management was very limited due mainly to a lack of public participation mechanisms [16]. Nowadays, partly because of new communication technologies that enable citizens to be engaged in the processes of urban design and planning, there are opportunities to provide citizens with a new role in decision-making [21]. The increasing exposure to the impacts of urban floods also provides incentives to planners, engineers and architects to integrate water in the urban design process. However, it is hard for all stakeholders involved (including residents) to recognize the values of such an integrated water management approach. The benefits are often remote and to some extent uncertain, while the extra costs are upfront. As a result, residents take it for granted that flood management has been appropriately considered by the government. Components of the sponge city concept have been applied in many new construction projects in Wuhan, but residents do not recognize these interventions as being part of this concept. For example, permeable parking lots, green roofs and small gardens have already been used in real estate developments. However, residents and some developers are not always aware of their functions 
and their ability to potentially reduce flood risk. In practice, the design of sponge city construction should be integrated into the urban landscape while acknowledging the environmental benefits. Developers tend to spend more on those two aspects than on flood safety alone. It is therefore crucial for the wider uptake of the sponge city construction to take all these multiple benefits into account.

To answer the question of "who should bear the cost for sponge city?", the interviews yielded the following insights. From the developers' perspective, the extra costs should be transferred to potential homebuyers regardless of their WTP. Most experts interviewed admitted that under the current booming real estate market conditions, developers should be able to transfer the costs of sponge city construction to homebuyers. However, they also shared the opinion that the construction costs of collective, local-level flood protection infrastructure, such as flood embankments, pumps and ponds, should be covered by the municipality through local taxes.

\subsection{Research Findings from Secondary Data Analysis}

\subsubsection{The Relationship between Flooding Events and House Prices}

Wuhan has the features of a subtropical monsoon climate, with the summer season being from June to September. During those months, the amount of rainfall usually varies between 200 and $300 \mathrm{~mm}$ per month, and this amount of rainfall is larger than the total rainfall in the remaining months of the year [22]. Figure 8 illustrates that, in 2016, monthly rainfall was significantly higher in the months from June to August than in the other months.

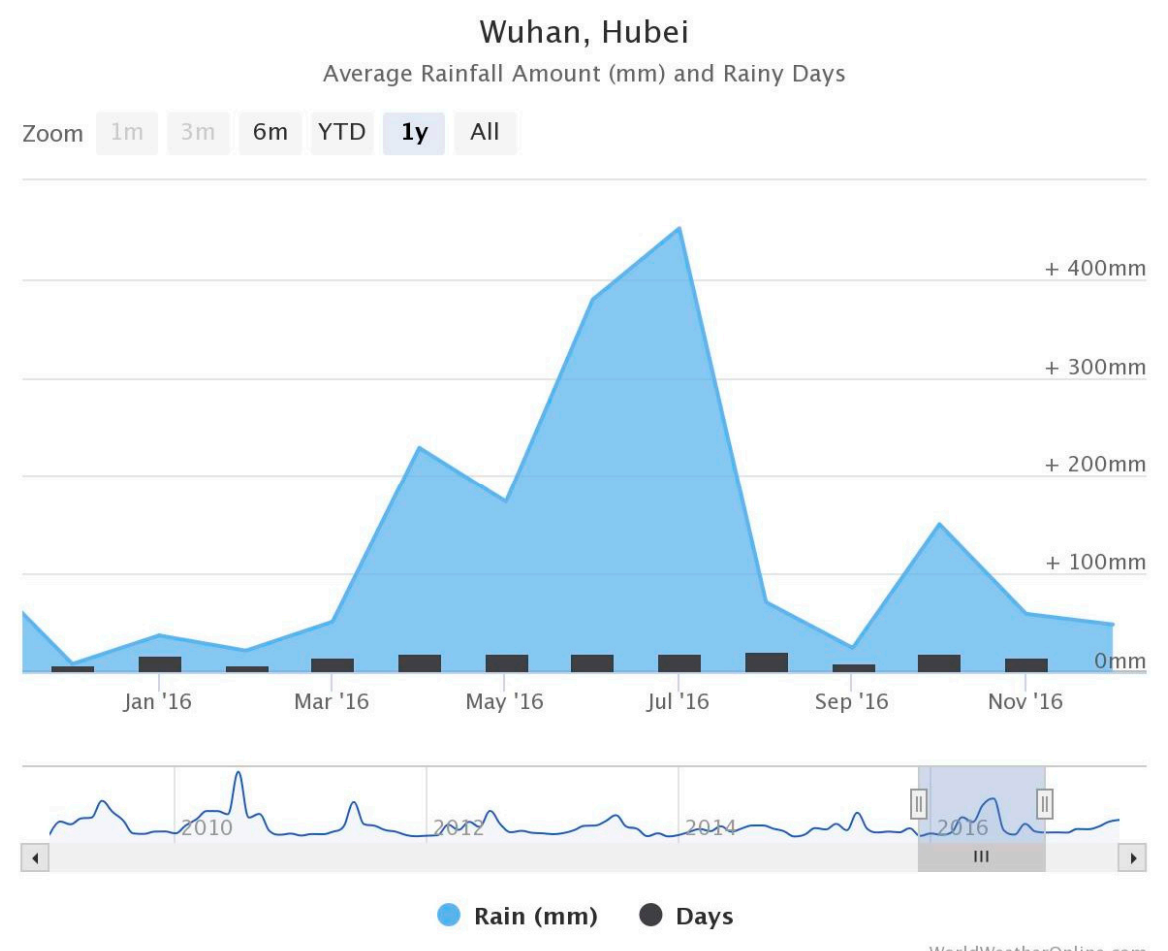

Figure 8. Monthly rainfall in Wuhan (2016). Data source: World Weather Online.

The heavy rainfall that hit Wuhan in July 2016 (see Section 1) caused waterlogging of many neighborhoods across the city. The data in Table 6 show that the residential house transaction prices in most districts were lower than usual that July. Only two districts experienced residential house transaction price increases. Both districts were sponge city construction areas. It seems plausible to assume that the flood event reduced the value of homes that were subject to serious flooding. As a result, the district's monthly average house transaction price dropped in July 2016. 
Table 6. Monthly percentage change of transaction prices for housing in central districts of Wuhan in 2016.

\begin{tabular}{ccccccccccccc}
\hline \multirow{2}{*}{ Districts } & \multicolumn{8}{c}{ Change of Transaction Prices for Residential Houses Across Districts by Month, \% } \\
\cline { 2 - 14 } & Jan. & Feb. & Mar. & Apr. & May & Jun. & Jul. & Aug. & Sep. & Oct. & Nov. & Dec. \\
\hline Qiaokou & $\mathrm{s}$ & -10 & 0 & -5 & 0 & 9 & -3 & 3 & 2 & 2 & -3 & -3 \\
Wuchang & 3 & 2 & 0 & 6 & 2 & 3 & -4 & 1 & 5 & -36 & -4 & 6 \\
Jiangan & -1 & 6 & 2 & -2 & 6 & 2 & -8 & 9 & 39 & -16 & -8 & -5 \\
Jianghan & 11 & -2 & -5 & 16 & -10 & -8 & -5 & 15 & 3 & -8 & -5 & -31 \\
Hongshan & -1 & 1 & 7 & 1 & 3 & 10 & -10 & -7 & 26 & -8 & -10 & -12 \\
Qingshan * & 16 & -9 & -2 & 5 & 1 & 10 & 6 & -5 & 13 & 3 & 6 & -15 \\
Hanyang * & -2 & 0 & 2 & 7 & 0 & 0 & 4 & 3 & 4 & 9 & 4 & 11 \\
\hline
\end{tabular}

* Refers to districts that were sponge city pilots. Source: China Index Academy, 2017.

\subsubsection{The Comparison between Sponge City Area and Non-Sponge City Area}

Figure 9 shows the trend of the annual average transaction price for houses in Wuhan central areas over the past six years. Quantitative data on housing transaction prices in Wuhan (both sponge city areas and non-sponge city areas) are from the China Index Academy (accessed in 2017). Quantitative data on land transaction prices in Wuhan (both sponge city areas and non-sponge city areas) are from the Wuhan Land Transaction Center (accessed in 2017). The non-sponge city areas covered five districts: Jianghan, Jiangan, Hongshan, Wuchang and Qiaokou. The sponge city areas included two districts: Hanyang and Qingshan. From 2012 to 2014, both trend lines are very similar, indicating no difference between the average unit house transaction prices of non-sponge city and sponge city areas. In 2015, the trend line representing the sponge city area dropped by more than $10 \%$ to $-1 \%$. A plausible explanation for this abrupt change is the sudden increase of the housing supply in Qingshan District. In the past five years, the average housing supply was around 2300 houses per year, but the supply in 2015 reached a level of 6900 houses. This increased supply caused the average unit house transaction price of Qingshan District to decrease from 9520 yuan per square meter to 8743 yuan per square meter. In 2016 as well as the first half of 2017, the trend line of the sponge city areas was above that of the non-sponge city areas, suggesting that the average unit house transaction prices in sponge city areas were at a level higher than those of the non-sponge city areas. It seems, therefore, reasonable to speculate that sponge city construction may have had a positive influence on housing transaction prices in this period. This is a field of research that needs more attention in the future.

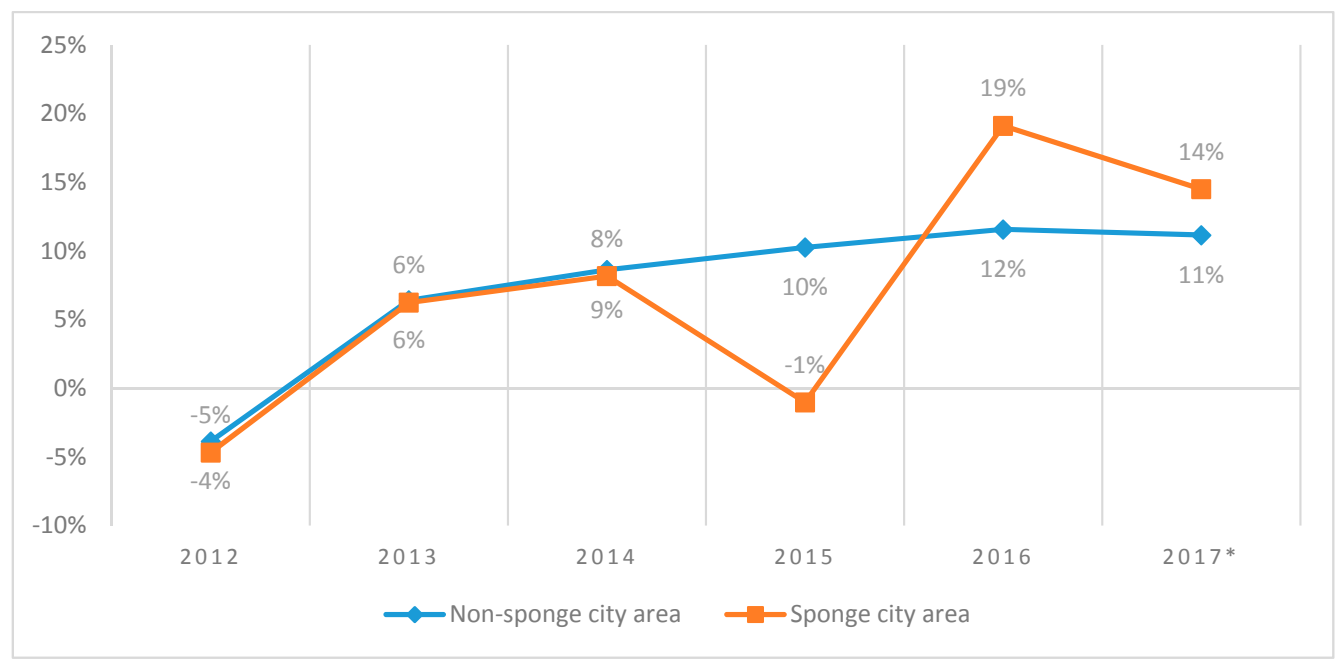

Figure 9. Annual average unit housing transaction prices in Wuhan central areas in the period 2012-2017. Source: China Index Academy, 2017. 


\section{Conclusions}

\subsection{Research Conclusion}

\subsubsection{Flood Risk Perceptions of Residents in Wuhan}

A very large proportion (96.7\%) of the residents of Wuhan has been exposed to flooding in either a direct or an indirect way. Apart from the scale of exposure, the flood frequency was also high, as $69 \%$ of residents claimed to suffer from urban flooding at least once a year. Disruption to the public transportation system and roads caused by flooding were perceived to be the most stressful impacts of urban flooding on the residents of Wuhan. Flooding of residential properties ranked as the second-most stressful impact. The most important type of interventions to manage flood risk in the study area were considered to be recovery actions. Preventive actions at household level had been taken by $19 \%$ of the residents, even though most households valued the effectiveness of preventive actions as low in terms of reducing flood risk. Compared with the large-scale exposure to, and the high frequency nature of, urban floods in Wuhan, residents' attitudes toward flood risk seemed to be relatively modest. Only $14 \%$ of respondents considered their flood experiences to be "traumatic". Most residents classified them merely as "annoying". The results of this research show that flooding had a negative impact on property values, as $86 \%$ of respondents thought that the value of their residential property would decrease if it had been flooded during the recent rainfall events that occurred in Wuhan. However, $48 \%$ of respondents believed that the value of residential properties could recover after the floods when adequate flood proofing measurements had been taken.

\subsubsection{Residents' Perceptions of Sponge City and Its Functions}

Although the term "sponge city" is a relatively academic concept in urban water management, more than $66 \%$ of the residents were familiar with the concept. Half of those residents had merely heard of the concept and had a limited understanding of its meaning. Past flood experiences and the level of understanding of the sponge city concept were the two factors that had an influence on residents' perceptions and valuing of the sponge city concept. A reduction of flood risk and an increase of the coverage of green space and public space are the three main benefits that are being delivered by sponge city construction. More than $70 \%$ of respondents acknowledged these functions of the sponge city. Most of the respondents expected that the sponge city concept would improve the livability of their neighborhood. They perceived an increase of the coverage of green space to be the most important factor that contributes to a better living environment. The sponge city's ability to improve the safety level of the area was acknowledged by most of the residents. This was particularly true for those who suffered frequently from flooding. However, one fifth of respondents still had reservations about its actual effectiveness in terms of reducing the city's flood risk.

\subsubsection{Residents' Willingness to Pay for Sponge City}

Residents' exposure to floods had an influence on their perception of the impact of sponge city construction on property values. About $83 \%$ of respondents believed that sponge city construction would increase the value of those houses located in the area covered by the construction, and $67 \%$ of respondents thought that sponge city construction would increase the land value of the area that the construction covers. Most respondents assumed that the range of increase would be less than $5 \%$ of the property's original value.

Residents' willingness to pay for sponge city construction was affected by the expected multiple benefits of the sponge city. Although $76 \%$ of respondents were willing to pay for the sponge city through an increase of their housing prices, the degree of their WTP was related to the real estate market in Wuhan. The current booming housing market in Wuhan reduces residents' bargaining power. Therefore, their WTP is relatively strong. It is highly plausible that residents' WTP would decrease if the real estate market became less volatile in the future. The actual transaction data supports the 
assumption that flood events have a negative influence on housing prices. From the actual transaction data, it is reasonable to infer that sponge city construction may contribute to an increment of housing transaction prices, but the degree of the price increase is hard to estimate.

In summary, most of the residents were willing to pay in the form of increased housing prices for sponge city construction, but to a limited extent only. The drivers of their WTP were a better living environment and lower flood risk. Under these conditions, low impact developments might seem to be the most suitable way to meet residents' requirements.

\subsubsection{Sponge City Concepts and Residents' Perceptions of Housing Values}

The research results support the theory that sponge city constructions are one of the factors that influence property values and prices in urban areas. Based on the research data, $83 \%$ of residents interviewed believed that sponge city construction in Wuhan would increase the value of houses located in the area covered by sponge city. The sponge city concept has an impact on residents' perceptions of housing values in two ways. The first relates to residents' perceptions of flood risk. The data analysis reveals that the flood exposure level of residents had an influence on residents' perceptions of flood risk. For those residents who have been exposed to flooding, property values were strongly impacted by the perceived flood risk level. The higher the level of flood exposure (in terms of frequency and/or impact), the more the residents believed that housing values will be positively affected by sponge city construction. The second relates to the residents' recognition of the multiple benefits provided by sponge city construction. Past experiences and degrees of exposure to flooding, and understanding of the sponge city concept, were considered to be the main factors influencing residents' confidence in the sponge city concept. The achievement of an improved living environment was valued as the most significant benefit by respondents in Wuhan.

This study reveals that, in the context of Wuhan, the sponge city concept impacts housing values. Most residents believed that sponge city construction has increased housing values by a maximum of $5 \%$ of the original housing value. Finally, both the results of the questionnaires and the in-depth interviews indicate a wide degree of support for the view that the costs of sponge city construction should be shared between the private sector and the government. This view holds that it is the government's responsibility to invest in basic infrastructure such as collective flood protection infrastructure including embankments, drainage systems and retention ponds, and that it is the private sector's responsibility to invest in multiple benefit interventions that enhance the livability of urban neighborhoods.

\subsection{Recommendations}

Although more than half of the residents were willing to pay for the sponge city concept, they valued equally—or even more importantly—the multiple benefits such as improved livability and a better living environment associated with the concept, instead of flood safety gains alone. Therefore, the first recommendation is that designers, architects and engineers of sponge city constructions should be fully aware of the opportunities the concept may offer to create sponge city interventions, which maximize multi-functional uses. This study reveals that residents are willing to pay for these additional benefits.

The second recommendation relates to public-private partnerships. PPPs are generally considered to be an important potential funding source of the sponge city program. However, in the current pilot period, the government is playing a leading role in the sponge city construction process, including finance, but private engagement is virtually absent. This study shows that there are opportunities for PPPs to engage in the process of sponge city construction. Promotion of the PPP model and the participation of social capital require market-oriented construction and an understanding and valuing (monetizing) of the multiple benefits associated with sponge city construction.

Finally, it is important to note here that care must be taken to consider the outcomes of this study for other Chinese cities, as local contextual differences may have an impact on citizens' perceptions. 
Although this study provides useful information for other Chinese cities, it is recommended to validate the outcomes if applied to another city using a similar type of survey and field research.

Author Contributions: Conceptualization, Methodology, Formal analysis, Investigation, Data Curation and Writing- Original Draft preparation, S.Z.; Conceptualization, formal analysis, and writing (both original draft preparation and review and editing), C.Z., P.R.; Formal analysis, Y.J.

Acknowledgments: The authors wish to thank the Wuhan Housing Security and Housing Management Authority, the Wuhan Municipal Development and Reform Committee, and the Wuhan Land Use and Urban Spatial Planning Research Center for their technical assistance provided during the research.

Conflicts of Interest: The authors declare no conflict of interest.

\section{Appendix A. Questionnaire Used in This Study}

Personal information

1. What's your age currently?

- Below 18

- $18-30$

- $\quad 31-45$

- $46-55$

- $56-65$

- $\quad$ Above 65

2. What's your gender?

- female

- male

3. Which is your education level?

- Senior school or below

- University or college degree

- Post-graduate qualification

4. Which of district that your current residence locates in?

- Jianghan

- Jiangan

- Qiaokou

- Qingshan

- Wuchang

- Hongshan

- Hanyang

- Donghu Hi-tech development zone

- Wuhan economic development zone

- Others

Exposure to urban floods

5. Do you ever have exposure to urban floods in the past twenty years in Wuhan?

- Heavy exposure (once a year or more)

- Limited exposure (less than once a year)

- Observed other's exposure 
- No exposure

6. Which kinds of affects the urban floods had played on you and your asset?

- My neighbourhood was flooded, but my house was well protected

- My residence was flooded (flood water entered my house)

- My office or work place was covered by water

- The transportation process was affected by flood

- Loss or damages of personal assets

- Others affects made by floods

7. How do you feel about the experience of these floods?

- Traumatic (e.g., if possible would change the residence for a safe and flood free one)

- Annoying

- Neutral/indifferent

8. What's the frequency that your house has been affected by urban floods (in the past 10 years)?

- More than once a year

- Once a year

- Once per two years

- Once per three to five years

- Once per six to ten years

- Less than once per ten years

9. Which kind of measurements below that do you prefer to take when responded to flooding?

- Take recovery actions: flood resilient repair/replace/ cleaning/

- Take preventive actions to protect from flooding water entering the house (such as flood boards to close the door(s), sand bags, remove valuable assets to dry place)

- $\quad$ Leave the house

- Take no action (Except for cleaning the house after the flood)

10. Do you think the property value of areas that heavily affected by urban floods will decrease after the urban floods?

- Yes

- No

- I don't know

11. Do you think the government had taken effective measurements to reduce the effects played by the flood?

- Yes

- No

- I don't know

General perception of the sponge city program

12. Do you know the concept of the sponge city?

- Yes

- No

- Heard, but have no idea of what does it mean 
'The general objectives of the concept entail 'restore' the city's capacity to absorb, infiltrate, store, purify, drain and manage rainwater and 'regulate' the water cycle as much as possible to mimic the natural hydrological cycle.' [23].

13. Do you know that Wuhan government has conducted the construction of the sponge city?

- Yes

- No

14. Do you think that the construction of the sponge city can effectively reduce the negative effects made by floods on your property/house?

- Yes

- No

- I don't know

15. To what extent you think a reduction of flood risk (change of occurrence), which is the result of the construction of the sponge city, will increase the residential value of areas that the construction covers?

- Increased less than $2 \%$ of the house value

- Increased the house value from $2 \%$ to $4.9 \%$

- Increased the house value from $5 \%$ to $7.9 \%$

- Increased the house value from $8 \%$ to $10.9 \%$

- Increased more than $11 \%$ of the house value

- Make no effect on house value

16. To what extent you think a reduction of flood risk (change of occurrence), which is the result of the construction of the sponge city, will increase the land value of areas that the construction covers?

- Increased less than $2 \%$ of the land value

- Increased the land value from $2 \%$ to $4.9 \%$

- Increased the land value from $5 \%$ to $7.9 \%$

- Increased the land value from $8 \%$ to $10.9 \%$

- Increased more than $11 \%$ of the land value

- Make no effect on land value

- I have no idea on this issue

Perception of the positive effects brought by the sponge city program

17. Do you think that the construction of the sponge city can effectively improve the safety level of the area that the construction covers?

- Yes

- No

- I don't know

18. To what extent you think the increasing level of safety (reduction of impact/consequences) at the household level, which is the result of the construction of the sponge city, will increase the residential value of areas that the construction covers?

- Increased less than $2 \%$ of the house value

- Increased the house value from $2 \%$ to $4.9 \%$

- Increased the house value from $5 \%$ to $7.9 \%$ 
- Increased the house value from $8 \%$ to $10.9 \%$

- Increased more than $11 \%$ of the house value

- Make no effect on house value

19. To what extent you think the increasing level of safety (reduction of impact/consequences) at the household level, which is the result of the construction of the sponge city, will increase the land value of areas that the construction covers?

- Increased less than $2 \%$ of the land value

- Increased the land value from $2 \%$ to $4.9 \%$

- Increased the land value from $5 \%$ to $7.9 \%$

- Increased the land value from $8 \%$ to $10.9 \%$

- Increased more than $11 \%$ of the land value

- Make no effect on land value

- I have no idea on this issue

20. Do you think that the construction of the sponge city can effectively improve the coverage rate of green space of area that the construction covers?

- Yes

- No

- I don't know

21. To what extent you think the improvement of the coverage rate of green space, which is the result of the construction of the sponge city, will increase the residential value of areas that the construction covers?

- Increased less than $2 \%$ of the house value

- Increased the house value from $2 \%$ to $4.9 \%$

- Increased the house value from $5 \%$ to $7.9 \%$

- Increased the house value from $8 \%$ to $10.9 \%$

- Increased more than $11 \%$ of the house value

- Make no effect on house value

22. To what extent you think the improvement of the coverage rate of green space, which is the result of the construction of the sponge city, will increase the land value of areas that the construction covers?

- Increased less than $2 \%$ of the land value

- Increased the land value from $2 \%$ to $4.9 \%$

- Increased the land value from $5 \%$ to $7.9 \%$

- Increased the land value from $8 \%$ to $10.9 \%$

- Increased more than $11 \%$ of the land value

- Make no effect on land value

- I have no idea on this issue

23. Do you think that the construction of the sponge city can effectively improve the coverage rate of public space of area that the construction covers?

- Yes

- No

- I don't know 
24. To what extent you think the improvement of the coverage rate of public space, which is the result of the construction of the sponge city, will increase the residential value of areas that the construction covers?

- Increased less than $2 \%$ of the house value

- Increased the house value from $2 \%$ to $4.9 \%$

- Increased the house value from $5 \%$ to $7.9 \%$

- Increased the house value from $8 \%$ to $10.9 \%$

- Increased more than $11 \%$ of the house value

- Make no effect on house value

25. To what extent you think the improvement of the coverage rate of public space, which is the result of the construction of the sponge city, will increase the land value of areas that the construction covers?

- Increased less than $2 \%$ of the land value

- Increased the land value from $2 \%$ to $4.9 \%$

- Increased the land value from $5 \%$ to $7.9 \%$

- Increased the land value from $8 \%$ to $10.9 \%$

- Increased more than $11 \%$ of the land value

- Make no effect on land value

- I have no idea on this issue

Summary

26. Compared with houses that do not construct under the sponge city concept, whether you will prefer to buy the houses that constructed under the sponge city concept? (Under the assumption that other factors are similar?)

- Yes

- No

- I don't know

27. To what extent you are willing to pay an extra cost for the construction of the sponge city in the area that your targeting house locates?

- Not pay any more for the sponge city

- Pay less than the $2 \%$

- Pay the extra cost from $2 \%$ to $4.9 \%$

- Pay the extra cost from $5 \%$ to $7.9 \%$

- Pay the extra cost from $8 \%$ to $10.9 \%$

- Pay more than $11 \%$ of the extra cost

\section{References}

1. Wang, Q.L. Effects of changing of water-route in Ming and Qing Dynasty. Jianghan Acad. 2013, 13, 108-113.

2. Today's Sydney. The Most Destructive Floods in Wuhan for 21th Century, 2016. Available online: http: //www.gzhphb.com/article/25/257574.html (accessed on 1 March 2016).

3. Ministry of Finance of the People's Republic of China. A Noticed of the Scheme of Subsidies on the Pilot Project of Sponge City Construction by Finance Department of Central Government, 2014. Available online: http://jjs. mof.gov.cn/zhengwuxinxi/tongzhigonggao/201501/t20150115_1180280.html (accessed on 1 March 2017).

4. The Office of Wuhan City Government. The Program of Functional Improvement of Waterfront Area in Wuhan, 2014. Available online: http://www.wh.gov.cn/hbgovinfo_47/szfggxxml/zcfg/bgtwj/201611/ t20161110_93233.html (accessed on 1 March 2017). 
5. Yeo, S. Effects of disclosure of flood-liability on residential property values. Aust. J. Emerg. Manag. 2003, 18, $35-44$.

6. Montz, B.E. Hazard area disclosure in New Zealand: The impacts on residential property values in two communities. Appl. Geogr. 1993, 13, 225-242. [CrossRef]

7. Lamond, J.; Bhattacharya-Mis, N. Risk perception and vulnerability of value: A study in the context of commercial property sector. Int. J. Strateg. Prop. Manag. 2016, 20, 252-264.

8. Eves, C.; Wilkinson, S. Assessing the immediate and short-term impact of flooding on residential property participant behaviour. Nat. Hazards 2014, 71, 1519-1536. [CrossRef]

9. Tobin, G.A.; Montz, B.E. The flood hazard and dynamics of the urban residential land market. Water Resour. Bull. 1994, 30, 673-685. [CrossRef]

10. Troy, A.; Romm, J. Assessing the Price Effects of Flood Hazard Disclosure Under the California Natural Hazard Disclosure Law (AB 1195). J. Environ. Plan. Manag. 2003, 47, 1-35. [CrossRef]

11. Botzen, W.J.W.; van den Bergh, J.C.J.M. Risk attitudes to low-probability climate change risks: WTP for flood insurance. J. Econ. Behav. Organ. 2012, 82, 151-166. [CrossRef]

12. Wang, Y.; Sun, M.; Song, B. Public perceptions of and willingness to pay for sponge city initiatives in China. Resour. Conserv. Recycl. 2017, 122, 11-20. [CrossRef]

13. Daun, M.C.; Clark, D. Flood Risk and Contingent Valuation Willingness to Pay Studies: A Methodological Review and Applied Analysis; Technical Report \#6; Institute for Urban Environmental Risk Management, Marquette University: Milwaukee, WI, USA, 2000.

14. McLean, D.; Mundy, B. The Addition of Contingent Valuation and Conjoint Analysis to the Required Body of Knowledge for the Estimation of Environmental Damages to Real Property. J. Real Estate Pract. Educ. 1998, 1, 1-19.

15. Shao, W.; Zhang, H.; Liu, J.; Yang, G.; Chen, X.; Yang, Z.; Huang, H. Data integration and its application in the sponge city construction of China. Procedia Eng. 2016, 154, 779-786. [CrossRef]

16. Yang, Y.; Lin, G. A review on sponge city. South Archit. 2015, 3, 59-64.

17. Wuhan Statistics Yearbook 2016; No. 29; China Statistics Press: Beijing, China, 2017.

18. Renn, O. Individual and social perception of risk. In Ökologisches Handeln als Sozialer Prozess. Themenhefte (Schwerpunktprogramm Umwelt/Programme Prioritaire Environnement/Priority Programme Environment); Fuhrer, U., Ed.; Birkhäuser: Basel, Switzerland, 1995; pp. 27-50.

19. Birkholz, S.; Muro, M.; Jeffrey, P.; Smith, H.M. Rethinking the relationship between flood risk perception and flood management. Sci. Total Environ. 2014, 478, 12-20. [CrossRef] [PubMed]

20. Wang, M.; Sweetapple, C.; Fu, G.; Farmani, R.; Butler, D. A framework to support decision making in the selection of sustainable drainage system design alternatives. J. Environ. Manag. 2017, 201, 145-152. [CrossRef] [PubMed]

21. Wehn, U.; Rusca, M.; Evers, J.; Lanfranchi, V. Participation in flood risk management and the potential of citizen observatories: A governance analysis. Environ. Sci. Policy 2015, 48, 225-236. [CrossRef]

22. Monthly Rainfall in Wuhan (2016). World Weather Online. Available online: https://www.worldweatheronline. com/wuhan-weather-averages/hubei/cn.aspx (accessed on 5 July 2017).

23. Zevenbergen, C.; Boogaard, F. Sponge City Scoping Report; UNESCO-IHE: Delft, The Netherlands, 2016; 22p.

(C) 2018 by the authors. Licensee MDPI, Basel, Switzerland. This article is an open access article distributed under the terms and conditions of the Creative Commons Attribution (CC BY) license (http://creativecommons.org/licenses/by/4.0/). 